\title{
Liturgical inculturation or liberation? A qualitative exploration of major themes in liturgical reform in South Africa
}

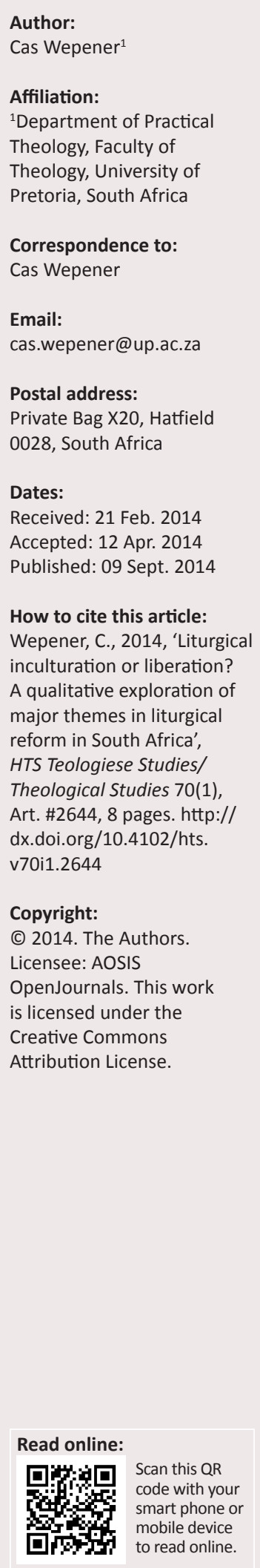

In this article, the notion of liturgical inculturation is revisited in the light of qualitative liturgical research conducted in local faith communities as well as with church leaders in South Africa regarding liturgical reform over recent decades. Two central themes were identified as representing important changes that occurred and are still occurring in the liturgy in South Africa roughly since Vatican II and the promulgation of Sacrosanctum Concilium. They are referred to here as 'the language of women' and 'the language of justice'. The concept of liturgical inculturation is revisited in the light of the ways in which these two 'languages' function and functioned in the liturgies of churches in South Africa. In conclusion, an argument is advanced for a more comprehensive understanding of the notion of liturgical inculturation in order to assist the liturgy to regain its prophetic voice in South Africa today.

\section{Introduction}

During the decades after Vatican II and the promulgation of Sacrosanctum Concilium (Constitution on the Sacred Liturgy) as the first document issued by the Second Vatican Council in 1963, liturgical reform swept over large parts of the world, including Africa. In many countries in Africa, experiments were carried out regarding liturgical inculturation, of which the so-called Zaire Rite (Egbulum 2005:688-693) of the Roman Catholic Church was probably the best known example. However during the very same time, very little happened along similar lines in South Africa in mission-initiated churches (MIC) $)^{1}$ or so-called mainline churches. ${ }^{2}$ The changes or organic 'reform' that was taking place in the African Initiated Churches (AICs) and Pentecostal churches at this time was largely in line with a re-appreciation of aspects of Traditional African Religion within the worship of these churches. The language of the liturgy in South Africa in that period was, to generalise, not the language of inculturation but the language of liberation or justice ${ }^{3}$ (cf. De Gruchy 1986; Hay 1997; Wepener 2002, 2011a) pertaining to both worship and preaching in most churches. Also the opposite kind of language, a language that supported the policy of apartheid, was to be found in the liturgy of some other MICs that supported apartheid. In other words, it was through language in the liturgies that the different liturgical elements such as prayers and sermons supported the system of apartheid. Today however, in the year 2014, the South African context has changed and along with that also the language in the liturgy of the churches. In particular, the liturgies of MICs in South Africa have to a large extent lost the language of justice whilst in the academic literature various voices are calling for liturgical inculturation ${ }^{4}$ (De Klerk 2001; Müller 2007; Wepener 2006; Wepener \& Meyer 2012). Simultaneously in many churches and other faith communities or faith-based organisations, there are indeed deliberate attempts at liturgical inculturation, as is also reflected in recent research projects (e.g. Flynn 2011; Nyawuza 2013).

In this article, the general themes of inculturation and justice in the liturgy will be explored by focusing on two related issues or what will be called languages of the liturgy, namely the issue or language of women and liturgy and the language of justice and liturgy. During the course of 2012 and 2013, qualitative research was conducted in order to investigate changes or reforms that took place in worship and liturgy over recent decades in sub-Saharan Africa ${ }^{5}$ (cf. Wepener 2013). 1.For the distinction between 'African initiated' and 'mission initiated', see Oduro et al. (2008:6).

2.African Initiated Churches (AIC) as well as neo-Pentecostal churches are a different matter, seeing that the reforms that took place in those churches were more of an organic development than liturgical reform in the strict sense of the word (cf. Wepener 2013).

3.This language of justice was indeed a form of liturgical inculturation, given the particular context. However, the concept inculturation is often mistakenly understood as pertaining to cultural realities that do not include the domain of politics, and this is exactly the subject of this article.

4. For more on liturgical inculturation not specifically regarding the South African context, see also Egbulum (2005), Chupungco (2010) and Phan (2006). Inculturation as such has also been a topic of academic discourse in, for example, the work of Bosch (1991) as well as Shorter (1998).

5.For the geographical choice of 'sub-Saharan Africa' see De Klerk (2012:v-x). 
Apart from a literature study and data collection on ritual and liturgical practices at grassroots level by the author of this article in local communities for the past 14 years, which served as source material, South African church leaders were interviewed for the specific purpose of this research. All the questions posed to the interviewees were related to the theme of liturgical reform as well as language in the liturgy of the respective churches in which they serve. In general, the research results emerging from these interviews and observations can be categorised into two distinct groups of themes: firstly, changes related to a distinctly African cultural context and, secondly, a smaller group of two themes related to issues of gender and justice. To a large extent, both of these groups of themes relate to liberation or emancipation, but they cannot be separated neatly. However, the latter is to a greater extent connected to the particular socio-political context of apartheid.

The former group of themes regarding the particular African cultural context were reported on in a plenary presentation 'Liturgical "reform" in Sub-Saharan Africa: Some observations on worship, language and culture'. ${ }^{6}$ This article then reports on the second group of themes, namely that related to women and justice.

Thus, an outline of the methodology and the theoretical underpinning of the research will be followed by a discussion of the two mentioned aspects. The focus will be explicitly on exploring the relationship between the languages of justice and women as an example of liberation in relation to inculturation in the liturgy within the South African context. The question pertains to how these notions of liberation and inculturation can function in a complementary way, given the specific post-apartheid context of South Africa in 2014.

\section{Practical theology and ritual and liturgical studies}

Developments in the field of ritual and liturgical studies are similar to developments in other academic disciplines, including practical theology (Miller-McLemore 2012:2-3; Pieterse 2001:1-29) regarding the way in which theory and praxis are both incorporated into a research design. Practical theology as a field also developed from a theological discipline explicitly interested in the local congregation and offices of the church and was seen as a derived and applied science (Dingemans 1996:15-16; Miller-McLemore 2012:1). In our day, however, it has developed and became interested in religious praxis in more contexts than just that of the local congregation. Similarly, the alliance of liturgical studies with ritual studies (cf. Grimes [1990] 2010) has made it possible to broaden the object of research to liturgy beyond the text and also to liturgical rituals in more contexts than just the traditional Sunday liturgy (cf. Post 2001; Wepener 2011b).

These developments are important for the research on which this article reports, seeing that it makes it possible to

6.Plenary presentation delivered at the meeting of Societas Liturgica in Würzburg, Germany, on 09 August 2013. include both Sunday worship and ritual action that occurs in other contexts. It also acknowledges the need for including in the research the multiple contexts in which the liturgical rituals are being performed. This point will be developed further under the section on the Lutheran World Federation on worship and culture in this article.

\section{Participatory observation and semi-structured interviews}

As already mentioned, the data presented in this article are based on semi-structured interviews, amongst other sources (cf. Babbie \& Mouton 2001:289-291; Thumma 1998:203-208). The interviews were conducted with South African church leaders from a range of denominations, including Cardinal Wilfred Napier (Roman Catholic Church), Archbishop Richmond (Corinthian Church of South Africa, AIC), Professor Thias Kgatla (Uniting Reformed Church in southern Africa, MIC) as well as Pastor Daramola (Redeemed Christian Church of God, Pentecostal). The interviews thus included people from MICs as well as AICs and Pentecostal churches. All of these interviews were conducted in 2012 and 2013. Participatory observation and thick descriptions of actual worship services augmented the points made in these interviews.

Methodologically speaking, the aim of the research was to identify themes emanating from the participatory observation and the interviews by way of an inductive approach. The transcribed interviews and descriptions of worship services were then analysed by means of content analysis (cf. Babbie \& Mouton 2001:388-390) in order to identify key themes and summarise the content. The aim was to look for significant recurring themes pertaining to liturgy in liturgical reform. Eventually categories were established from the raw data and the content arranged in seven categories, which were then divided into two groups, one group consisting of five categories and the other consisting of two. The five categories include the language of the body, the language of the (evil) $\mathrm{S} /$ spirit(s), the language of power (or materialism), the (literal) language of the Bible (especially the Old Testament) and the language of healing (cf. Wepener 2013). The second group of two categories includes the language of women and the language of justice, which as has been mentioned in the introduction is the focus of this article. With regard to this approach, the work of the South African practical theologian Pieterse (2014) and his analysis of sermons by making using of a system of coding as part of a Grounded Theory approach served as a methodological guide. In what follows, some descriptions of present-day worship in South Africa will be provided. After that, the two categories will be discussed and then the main question of the article, namely the relationship between liturgical inculturation and liberation, will be addressed on the basis of the data collected.

\section{Worship in South Africa - some current-day examples}

The array of expressions of worship that one can encounter in the South African liturgical landscape is not necessarily 
known to many academic scholars and liturgists. In order to bring readers somewhat closer to the phenomenon that is being explored in this article, namely the ritual-liturgical mosaic that represents Christian worship in South Africa today, three expressions of worship will briefly be described here, each with a concomitant photograph. The description will be restricted to Sunday worship. However, liturgical rituals enacted at various times and places have been part of the research endeavours of the author and was taken into account in putting forward the argument. The first description is of worship in an AIC in the village of Phepheni, Eastern Cape, South Africa. ${ }^{7}$

\section{Worship in a local African Initiated Churches church, Phepheni, Eastern Cape, South Africa}

The Corinthian Church of South Africa (CCSA) has a rich and varied worship life with many liturgical rituals (cf. Mbaya 2011; Wepener, Mbaya \& Barnard 2011) (Figure 1). Members gather weekly on Sunday afternoons for a four to five-hour long worship service that consists of circle dances to the beat of African drums and imibhobho. ${ }^{8}$ These bind together all the other worship elements: the readings from Scripture, preaching, sharing of prophecies and visions and healing rituals, as well as the opening invocation, during which both the Holy Spirit and the spirit of the founder known as the 'angel' - are invoked and the closing of worship by chanting the Lord's Prayer. These worship services are very lively. All the participants who are physically able to do so join in the circle dances, which occur regularly and at least between every other element of the worship service such as between Scripture reading and preaching. The service is conducted in a small round house or rondavel, which is ideal for the circle dance. Drums and horns produce loud music that ceases only when the priest asks for silence in order to do a reading or to preach or pray. Apart from the weekly worship services, various other rituals are conducted by the congregation, including rituals that involve ritual sacrifices of animals. Most of their worship is based on the Bible, to quote Archbishop Richmond: 'For everything we do in worship we have text from the Bible. It must be done exactly like the Bible says, especially the Old Testament.' It should be mentioned here that both men and women participate in leading worship although they tend to have different roles.

\section{Worship in the Jesus Dome, Durban, KwaZulu-Natal, South Africa}

According to Anderson (1999a:1), there is not an absence of liturgy in Pentecostal churches but, because of the spontaneity and enthusiasm, rather 'flexible oral liturgies memorised by Pentecostal congregations' in which all worshippers become active participants. In the worship service, the Holy Spirit is seen as an active participant along with the worship leaders and worshippers. This is also true

\footnotetext{
7.There are many more expressions of Christian worship in South Africa today However, the examples that were chosen represent the largest worshippin traditions, and smaller traditions such as orthodox worship or worship expressions that are to be found more in traditional white communities were omitted.
}

8.Large vuvuzela-type instruments made of tin.

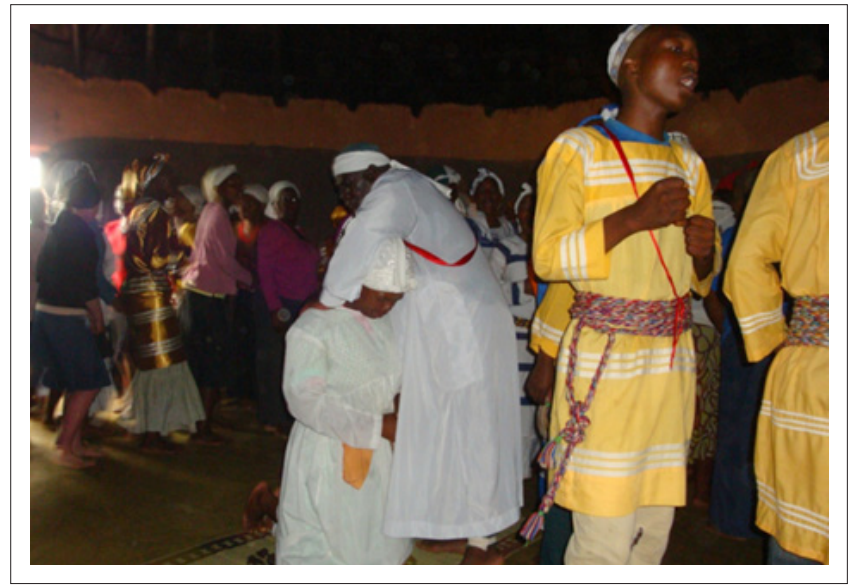

Source: Photograph taken by the author. All identifiable persons shown specifically consented to publication of this photograph.

FIGURE 1: Healing during the Sunday worship service.

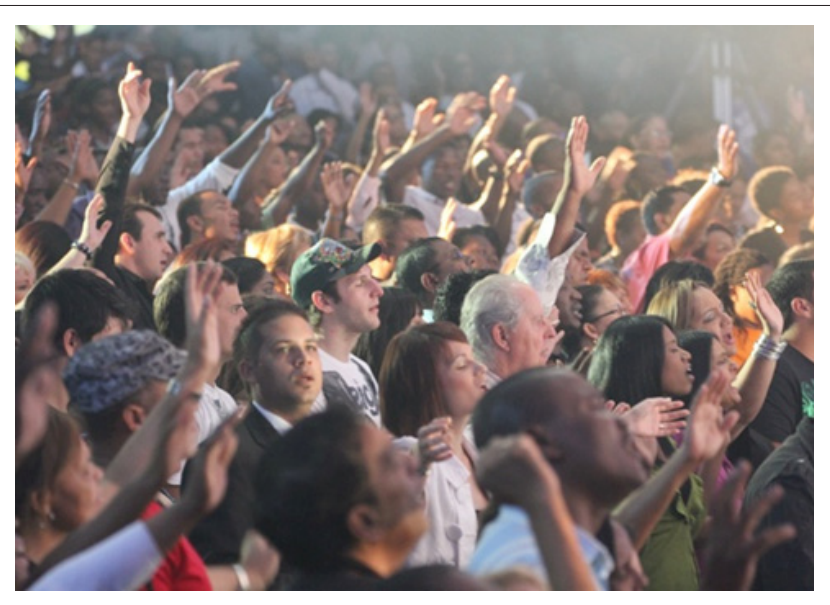

Source: Photograph obtained from http://www.dcc.org.za/ (viewed 04 November 2013) FIGURE 2: Praise and worship at the beginning of the Sunday worship service.

in the Jesus Dome in Durban and after a long phase of praise and worship, lasting more than 30 minutes, readings from Scripture and preaching, at least another hour is spent on worship acts pertaining to healing, prophecy, speaking in tongues and an 'altar call', during which people are called to conversion, and those who do respond to the call are prayed for (Figure 2). In all the worship services of this type that I have attended in cities such as Accra, Cape Town and Johannesburg, special attention to first-time visitors is also a fixed part of the worship service. 'This is our aim: People should no longer dance before their idols but here in worship before the living God with worship that leads to holiness and righteous living', were the words of Pastor Daramola during the interview with him.

\section{Worship in the Uniting Reformed Church, Langa, Cape Town}

A typical worship service in this congregation commences with traditional hymn singing (Figure 3). This is followed by an order of worship that is quite recognisable as being from the (Western) Reformed tradition with elements such as the reading of the law, confession, remission of sins, creed, epiclesis, Scripture reading and preaching. However, the 
preaching is performed in an extremely lively fashion with much bodily expression, the singing is accompanied by dancing and rhythmic clapping on Bibles, and throughout the worship service, worshippers will freely come and go as they wish without being a disturbance to anyone. To quote Prof. Kgatla on this physical expression of Reformed worship in an African context: 'We got rid of the organ, because it really interferes.'

These three examples can all three be termed 'African', although they belong to three distinctly different worshipping traditions, namely AIC, Pentecostal and MIC. The two themes that will now be discussed were integral to all the ritual-liturgical data collected in this research project as well as in the five semi-structured interviews. Based on the content analysis, two themes or 'languages' were grouped together as they recurred in all the interviews as well as in the field notes from the author's participatory observation over the past years. These two themes are the language of women and the language of justice.

\section{The language of women}

One theme that was unanimously raised by all the church leaders that I interviewed and that was observable in the worship in which I participated was that, as far as worship in their respective churches in Africa is concerned, women have gained a much stronger voice over the past decades. In fact, the archbishop of the fairly large AIC whom I interviewed is a woman, and the congregation in Phepheni, whose worship was described above, has three priests of whom one is a woman whilst the important liturgical role of the wife of the leader priest should also not be overlooked. In this AIC, for example, women used to have to wear their clothes in such a way that virgins could be distinguished from other women, according to most traditional African cultures, but this practice had been abolished along with other similar customs. ${ }^{9}$ Both on a general leadership level as well as on the level of liturgical leadership and liturgical participation, the language of women as a nascent phenomenon cannot be overlooked. This also became clear in the worship services described in the previous section. Thus regarding the theme of liturgical reform in sub-Saharan Africa, the changing role of women in worship is of pivotal importance.

According to Pretorius (2012:208-210), AICs have created a significant space for promoting social cohesion amongst women in Africa, despite a prevailing patriarchal culture. As far as worship is concerned, women preach, pray, prophesy, lead and participate in all acts of worship that men do. ${ }^{10}$ Even though examples of gender-exclusive liturgical language will indeed still be found in many worship services in South Africa, in general, worship as well as the body language used in worship has become more inclusive (cf. Dijk 1998:395-406; Ramshaw 1996).

9.Oduro et al. (2008:151) also refers to a similar phenomenon, namely that menstruating women are to sit in the corner during worship, known as sitting 'behind'. The practice of the CCSA to abolish such customs should thus be seen within a larger reality in which they are still intact in some other AICs.

10.Exceptions in this regard will be found in all three main groups (AIC, MIC and Pentecostal) and notably in the Roman Catholic Church.

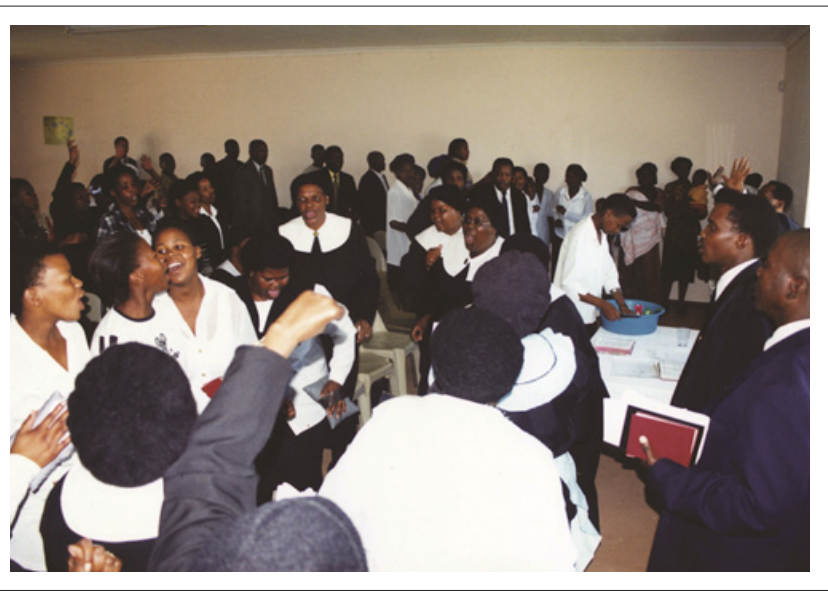

Source: Photograph taken by author. All identifiable persons shown specifically consented to publication of this photograph.

FIGURE 3: Hymn singing during an Easter liturgy.

However, distinctions based on gender still prevail, and in many liturgies in South Africa, the ritual space is divided along lines or boundaries based on gender and age. If the women are seated and standing in, say, the left part of the building, the men will be on the right, and often, the children will be grouped with the women. ${ }^{11}$ An in-depth analysis is needed of the role and place of women in worship in South Africa, but it is not the aim of this article. What is important, however, is the fact that, in all the liturgies that were incorporated in the research as well as all the interviews that were conducted, the changing role of women in worship was emphasised. This is even more significant given the literal hermeneutics of many churches in South Africa whereby the Bible will be read literally with regard to issues of ritual and liturgy. So, for example, a red heifer will be slaughtered and the ashes used for cleansing based on Numbers 19 (cf. Mbaya 2011; Wepener \& Ter Haar [forthcoming]), but women can in fact also perform liturgical roles as leaders and teachers. In this regard Oduro et al. (2008:144-147) make the significant observation that 'giftedness is more important than gender' with reference to various religious gifts. It is relevant to the theme of this article that several of these gifts are indeed either liturgical gifts or in some way related to the liturgy or (also) practised in the liturgy. Gifts mentioned include healing, seeing visions and prophesying, singing and composing songs, evangelising and leading (Oduro et al. 2008:145-146).

A book on reconciliation rituals in South African cultural contexts provides an example of a Mother's Day celebration in the vestry at a church directly after a Sunday-morning worship service (cf. Wepener 2009:168-169). During this brief celebration, the women were served tea and biscuits before the men were served. This is exceptional in traditional Xhosa culture where men are served before women and older people before younger people. Some of the men present bemoaned the fact that the women were served first and linked this to the loss of traditional culture and values 11.See, for example, in this regard the study by wepener $(2009: 167-168)$, which also
includes a floor plan of a church that indicates the seating arrangements according to gender and age. 
that ultimately results in violence and crime. This example highlights the importance of gender roles and provides a window into a culture of which the cult of the liturgy forms a part. Traditional patriarchal gender roles are still active, but a closer look at some of the practices uncovers some cracks in those patriarchal systems.

A last aspect in this regard that should be briefly explored here is the issue of power in relation to the changing role of women in worship and liturgy. In many AICs and Pentecostal churches in Africa, a large portion of the prophets and healers are in fact women. In her book on the healing ministry of Archbishop Milingo and with reference to the arrival of Christianity in the history of Zambia, Gerrie Ter Haar (1992) makes important observations regarding women, ritual and power. According to her, in the process of Christianisation, women lost the mediating role between the visible and invisible worlds which they had had in Traditional African Religion, a traditional role that is referred to by various scholars, including Oduro et al. (2008:142). In an attempt to regain some of the lost power, they found solace in the liturgical ritual of spirit possession (Ter Haar 1992:126). In an African context, the relation between liturgical participation, the leadership of women and issues of power (cf. Wepener 2006) should thus not be overlooked, and liturgical rituals such as spirit possession, exorcism, healing and prophetic utterances should be appreciated in this light. Here it could be meaningful to refer to Stringer's (2005) work A sociological history of Christian worship in which he, following Foucault, identified a so-called demotic discourse in Christian worship during the Late Medieval times when the people themselves started to perform liturgical rituals apart from the authorities of the day. The language of women in the organic reforms in liturgy in sub-Saharan Africa reflects such a demotic discourse whereas the more conservative theologies of many of these churches still discourages or even disallows women from taking on leadership roles. At grassroots level in practise, however, the language of women is becoming more prominent and will most probably continue as such, seeing that 'women constitute roughly a two-thirds majority of practising Christians in the growing world church' (Robert in Oduro et al. 2008:142).

This reflection on the language of women in liturgical reform in sub-Saharan Africa brings us to the language of justice, which is, of course, also closely related to issues of power.

\section{The language of justice (and worship Black Economic Empowerment)}

In reflecting on reform in worship in sub-Saharan Africa, one of the major shifts obviously has to do with colonial and post-colonial paradigms (Nealon \& Giroux 2012:154-170; Sharp 2012:422-431), which greatly influence the language of worship. Jomo Kenyatta once remarked (Jenkins 2011):

When missionaries came to Africa they had the Bible and we had the land. They said, 'Let us pray.' We closed our eyes. When we opened them, we had the Bible and they had the land. (p. 52)
Within the South African historical context, colonialism, apartheid and liberation from oppression impacted on the language in worship services in a variety of ways as was confirmed by Cardinal Napier, Archbishop Richmond and Prof. Kgatla.

In broad strokes, one can talk about a language of resistance permeating the worship in the churches under discussion in South Africa between the 1950s and the early 1990s. According to Cardinal Napier, the apartheid context impacted so severely on the churches that issues such as liturgical inculturation were basically not on the table as they were in the same period in Zaire (Democratic Republic of Congo). South African churches ignored these issues because they were preoccupied with issues pertaining to justice. In a denomination such as the Uniting Reformed Church of South Africa (URCSA), the language of resistance entered the worship services in the apartheid years. The AIC leader interviewed for this research, Archbishop Richmond, did not recall this as being part of the worship in those decades, and it is actually a well-known fact that, for example, Barnabas Lekganyane of the Zion Christian Church (ZCC) received Piet Koornhof in Moria and gave P.W. Botha the 'freedom of Moria' during the time of apartheid (cf. Müller 2011:15). ${ }^{12}$ Archbishop Richmond, as an AIC leader, rather views those years as the times when churches were still only observing the great feasts of the church such as Easter and Pentecost and not also all the new national holidays of post-apartheid South Africa, a situation they bemoan. These leaders are - just like the other church leaders - also not satisfied with the situation in postapartheid South Africa, and several said that their church has become a Black Economic Empowerment (BEE) church. By this, they mean that the churches are just following the government without taking a counter-cultural or prophetic stance. The latter is, however, also understandable. To quote one of the interviewees:

'Regarding language in the liturgy today, I can tell you that any language in a worship service that goes against our current government is nothing but a kiss of death.' (South African church leader)

Within a South African context, this is a serious matter that also influences worship and its reform, seeing that religion, just like politics, is seen as a source of power (cf. Ter Haar 2009; Ellis \& Ter Haar 2004).

With these two languages of liturgy in liturgical reform or the organic 'reform' of the churches' worship in mind, the concept of liturgical inculturation will now be revisited. The examples above make it is clear that the data also require a discussion of the concept of power. However, in the context under discussion in this article, power can only be understood within the framework of an African cosmology of the world of the spirits, which will also be briefly touched upon.

12.See in this regard also Anderson's (1999b) view that these moves were more strategic than generally thought. 


\section{The Lutheran World Federation on worship and culture}

There are many different definitions of liturgical inculturation such as 'a continuous process of criticalreciprocal interaction between cult (liturgy) and culture so that a totally new entity comes into being, namely an inculturated liturgy' (Wepener 2009:42). In this article, the main focus will be on the work of the Lutheran World Federation (LWF) in this regard and specifically also two statements issued by this body, namely the 'Nairobi Statement on Worship and Culture: Contemporary Challenges and Opportunities' (Lutheran World Federation [1996] 2007:286-290) and the 'Chicago Statement on Worship and Culture: Baptism and Rites of Life Passage' (Lutheran World Federation 1998). These documents were chosen since they are respected in the field of liturgical studies and used globally. In short, the dynamic relationship between worship and culture as explained in these documents may be summarised in the following statements:

- Worship is transcultural. (Worship has certain dynamics that are beyond culture.)

- Worship is contextual. (Worship reflects local patterns of speech, dress and other cultural characteristics.)

- Worship is counter-cultural. (Worship resists the idolatries of a given culture.)

- Worship is cross-cultural. (Worship reflects the fact that the body of Christ transcends time and space.)

The two aspects taken from the four statements above that will be the focus here are: 'contextual' and 'countercultural'. Over the past decades, it seemed that these two aspects were in a kind of tug of war in an on-going process of liturgical inculturation in the South African context and that these aspects were understood as dimensions of inculturation whilst the others had to do with liberation. During the apartheid years, the emphasis was much more on the counter-cultural (liberational) language of worship, and in the post-1994 years, counter-cultural language was replaced with the language of contextualisation (inculturation). There are those who will make a plea for turning the tide once again and to reclaim a counter-cultural language for the liturgy in the year 2014 in South Africa.

What I would like to argue here, in conclusion, is that these aspects are not mutually exclusive. On the contrary, contextualisation can be a counter-cultural act, as paradoxical as this might sound to some readers, and similarly, 'restoring' the more prophetic counter-cultural language to the liturgy can indeed also be a form of contextualisation. To contextualise can be empowering, and to empower could entail contextualisation. In order to explain what is meant, it is necessary to touch upon the African worldview within which these dimensions of contextualisation and the counter-cultural, which are part of liturgical inculturation, occur. Finally a proposal will be presented for a more comprehensive understanding of the concept of liturgical inculturation.

\section{The Spirit, the spirits and spiritual power}

A dualistic worldview is foreign to sub-Saharan Africa. In this African worldview, the spirit world is essential in understanding the context in which worship is enacted and also relates directly to the notion of causality, namely that there are both malevolent and benevolent spirits which influence people's lives (cf. Omenyo 2011:234). Seeking harmony and equilibrium is of the utmost importance (cf. Lumbala 1998:58; Mbiti 1999:3-7; Omenyo 2011:235), and rituals, liturgy and worship play a very important role in this regard. God is also believed to intervene directly in everyday life. 'Southern religion is not otherworldly or escapist, since faith is expected to lead to real and observable results in this world' (Jenkins 2011:98). In the spirit world, along with the idea of direct intervention and causality, the Spirit is seen as an 'enabling power' (Anderson 1999a:1) in and through participation in worship. The worship examples described in this article are ritual expressions of this worldview.

According to recent research by Wepener and Ter Haar (forthcoming), participation in AIC rituals and worship, which is strongly integrated in the world of the spirits, generates spiritual power that can become spiritual capital. This brief explanation is essential in order to advance the argument and come to a conclusion regarding the question that is posed in the title of this article, namely whether we should opt for the notion of liturgical inculturation or liturgical liberation?

\section{Conclusion}

In the light of the arguments above, it becomes clear that what is needed in sub-Saharan Africa in our day is a specific understanding of liturgical inculturation. Specifically, what is needed is an understanding that is relevant to the context, in the sense of addressing African cultural realities and a distinctly African worldview as well as the socio-political issues demanding liberation such as the two themes discussed in this research article. If we take the description of liturgical inculturation offered by the LWF, it is clear that there are four dimensions that need attention simultaneously. However, to think that the counter-cultural or liberatory thrust was needed in the 1960s to early 1990s in South Africa at the cost of the contextual and that the opposite is now true - namely, that it is now time for the contextual rather than the countercultural - would be a mistake and a misunderstanding of liturgical inculturation in an African context as such. Even worse, it would imply a reductionist approach to liturgy and worship in an African context, where the empirical and metaempirical are viewed as inseparable (Omenyo 2011:234). In the light of this, I want to argue that liturgical inculturation is at one and the same time both liberation and inculturation, and the concept should be reclaimed as such. Liturgical inculturation that goes deeper than merely so-called cultural aspects - such as liturgical dress or Eucharistic elements - and that truly engages with an African worldview of the spirit 
world will result in an inculturated liturgy that is empowering for those who participate in it. Schattauer (2007:126-129) also draws the distinction within the field of liturgical studies between publications related to 'cultural contexts', which are all specifically focused on 'the inculturation of liturgical practise', and 'liberation theologies', which are more focused on the experience of the marginalised. He adds that 'the aim is a practise of worship that promotes the justice and inclusion that characterise God's purpose' (Schattauer 2007:126, 128). With regard to liturgical inculturation, he indicates that there is an on-going debate between those advocating that worship embraces culture and those advocating that worship resists culture.

The qualitative ritual-liturgical exploration of enacted worship as well as the semi-structured interviews with church leaders taken together with the relevant literature that is reported on in this article make it clear that liturgical inculturation within the spirit world of Africa will most probably result in liberation and is as such simultaneously an act of contextualisation and empowerment towards developing a counter-cultural witness. Liturgical inculturation that adequately engages with the African worldview of the spirit will simultaneously be an act of liturgical inculturation as well as liturgical liberation, and the notion should be reclaimed as such.

\section{Acknowledgements Competing interests}

The author declares that he has no financial or personal relationship(s) that may have inappropriately influenced him in writing this article.

\section{References}

Anderson, A., 1999a, 'The gospel and culture in Pentecostal mission in the third world', paper presented at the 9th Conference of the European Pentecostal Charismatic Research Association, Missions Academy, University of Hamburg, Hamburg, July.

Anderson, A., 1999b, 'The Lekganyane's and prophecy in the Zion Christian Church', Journal of Religion in Africa XXIX(3), 285-312. http://dx.doi. org/10.1163/157006699x00368

Babbie, E. \& Mouton, J., 2001, The practise of social research, South African edn., Oxford University Press, Cape Town.

Bosch, D., 1991, Transforming mission: Paradigm shifts in theology of mission, Orbis Books Maryknoll, NY.

Chupungco, A., 2010, What, then, is liturgy?: Musings and memoir, Liturgical Press, Collegeville, MN.

De Gruchy, J.W., 1986, Cry justice!: Prayers, meditations and readings from South Africa, Collins Liturgical Publications, London.

De Klerk, B.J., 2001, 'Wisselwerking tussen liturgie en kultuur in die Suid-Afrikaanse konteks: Enkele vertrekpunte', PraktieseTeologie in Suid-Afrika 16(2), 57-75.

De Klerk, B.J., 2012, Liturgical involvement in society: Perspectives from sub-Saharan Africa, Potchefstroomse Teologiese Publikasies, Noordbrug.

Dijk, D.J.J., 1998, 'Inclusievetaal in de liturgie', in P. Oskamp \& N. Schuman (eds.), De weg van de liturgie: Tradities, achtergronden, praktijk, pp. 395-406, Meinema, Zoetermeer.

Dingemans, G.D.J., 1996, Manieren van doen: Inleiding tot die studie van de praktische theologie, Uitgeverij Kok, Kampen.

Egbulum, N.C., 2005, 'Mission and inculturation: Africa', in C. Wainwright \& K. Westerfield-Tucker (eds.), The Oxford history of Christian worship, pp. 678-695, Oxford University Press, Oxford.

Ellis, S. \& Ter Haar, G., 2004, Worlds of power: Religious thought and political practise in Africa, Hurst \& Company, London.

Flynn, D.S., 2011, "n Verkennend-beskrywende prakties-teologiese ondersoek na die waarde van "liturgiese" momente binne sport gemik op liturgiese inkulturasie', Mdiv proefskrif, Departement Praktiese Teologie, Universiteit van Pretoria.
Grimes, R.L., [1990] 2010, Beginnings in ritual studies, Ritual Studies International, Waterloo, CA.

Hay, M., 1997, 'Ukubuyisana. Reconciliation in South Africa', doctoral dissertation, Catholic Theological Union of Chicago, Chicago.

Jenkins, P., 2011, The next Christendom, 3rd edn., Oxford University Press, Oxford.

Lumbala, F.K., 1998, Celebrating Jesus Christ in Africa: Liturgy \& inculturation, Orbis Books, Maryknoll, NY.

Lutheran World Federation, [1996] 2007, 'Nairobi statement on worship and culture: Contemporary challenges and opportunities', in C.E. Farhadian (ed.), Christian worship worldwide: Expanding horizons, deepening practices, pp. 285-290, Eerdmans, Grand Rapids, MI.

Lutheran World Federation, 1998, 'Chicago statement on worship and culture: Baptism and rites of life passage', in Statements on Worship and Culture, viewed 04 November 2013, from http://www.worship.ca/

Mbaya, H., 2011, 'The socio-practical dimensions of isitshisa in the Corinthian Church of South Africa', HTS Teologiese Studies/Theological Studies 67(2), Art. \#930, 8 pages. http://dx.doi.org/10.4102/hts.v67i2.930

Mbiti, J.S., 1999, “'Hearts cannot be lent!": In search of peace and reconciliation in African traditional society', The Princeton Seminary Bulletin XX(1), 1-12.

Miller-McLemore, B., 2012, 'Introduction: The contributions of practical theology', in B. Miller-McLemore (ed.), The Wiley-Blackwell companion to practical theology, pp. 1-20, Blackwell Publishing Limited, Malden, MA.

Müller, B.A. 2007, 'Liturgy at the edges: Between doxology and domestication', Scriptura 96, 441-452.

Müller, R., 2011, African pilgrimage: Ritual travel in South Africa's Christianity of Zion, Ashgate, Farnham.

Nealon, J. \& Giroux, S., 2012, The theory toolbox: Critical concepts for the humanities, arts, \& social sciences, Rowman \& Littlefield Publishers, Inc., Lanham, MD.

Nyawuza, M.P., 2013, 'Lay participation in liturgical worship: A ritual-liturgical approach', ThM thesis, Department of Practical Theology, University of Pretoria.

Oduro, T., Pretorius, H., Nussbaum, S. \& Born, B., 2008, Mission in an African way: A practical introduction to African instituted churches and their sense of mission, Bybelmedia/CLF, Wellington.

Omenyo, C.N. 2011, 'New wine in an old wine bottle?: Charismatic healing in the mainline churches in Ghana', in C. Brown (ed.), Global pentecostal and charismatic healing, pp. 231-249, Oxford University Press, Oxford. http://dx.doi.org/10.1093/ acprof:oso/9780195393408.003.0012

Phan, P., 2006, 'Liturgical inculturation: Unity in diversity in the postmodern age', in K. Pecklers (ed.), Liturgy in a postmodern world, pp. 55-86, Continuum, London.

Pieterse, H.J.C., 2001, Preaching in a context of poverty, UNISA Press, Pretoria.

Pieterse, H.J.C., 2014, 'Religion in the public sphere and the well-being of the poor: A practical theological perspective', Verbum \& Ecclesia 35(2), 8 pages. http:// dx.doi.org/10.4102/ve.v35i2.852

Post, P.G.J., 2001, 'Introduction and application: Feast as a key concept in a liturgical studies research design', in P.G.J. Post, G. Rouwhorst, L. van Tongerend \& A. Scheer (eds.), Christian feast and festival: The dynamics of western liturgy and culture, pp. 47-77, Peeters Pers, Leuven.

Pretorius, H., 2012, 'The African Independent Churches (AICs) and social welfare in post-apartheid South Africa', in I. Swart, A. Gouws, P. Petterson, J. Erasmus \& F. Bosman (eds.), Welfare, religion and gender in post-apartheid South Africa: Constructing a south-north dialogue, pp. 205-223, SUN Press, Stellenbosch.

Ramshaw, G., 1996, Liturgical language: Keeping it metaphoric, making it inclusive, American Essays in Liturgy, The Liturgical Press Collegeville, MN.

Schattauer, T.H., 2007, 'Research report: Liturgical studies: Disciplines, perspectives, teaching', International Journal of Practical Theology 11, 106-137. http://dx.doi. org/10.1515/IJPT.2007.8

Sharp, M.M., 2012,'Globalization, colonialism, and postcolonialism', in B. MillerMcLemore (ed.), The Wiley-Blackwell companion to practical theology, pp. 422-431, Blackwell Publishing Limited, Malden, MA.

Shorter, A., 1998, Towards a theology of inculturation, Orbis Books, Maryknoll, NY.

Stringer, M.D., 2005, A sociological history of Christian worship, Cambridge University Press, Cambridge, UK. http://dx.doi.org/10.1017/CBO9780511614675

Ter Haar, G., 1992, The spirit of Africa: The healing ministry of Archbishop Milingo of Zambia, Hurst \& Company, London.

Ter Haar, G, 2009, How God became African: African spirituality and western secular thought, University of Pennsylvania Press, Philadelphia, PN.

Thumma, S.L., 1998, 'Methods for congregational study', in N.T. Ammerman, J.W. Carroll, C.S. Dudley \& W. McKinney (eds.), Studying congregations: A new handbook, pp. 196-240, Abingdon Press, Nashville, TN.

Wepener, C.J., 2002, 'Still because of the weakness of some?: A descriptive exploration of the Lord's Supper in South Africa, 1948 - 2002', Jaarboek voor liturgie-onderzoek 18, 139-158.

Wepener, C.J., 2006, 'Participation and power: Opportunities for method and theory in liturgical research from a changing (Dutch Reformed) South African liturgical landscape', Jaarboek voor liturgie-onderzoek 22, 49-66.

Wepener, C.J., 2009, From fast to feast: A ritual-liturgical exploration of reconciliation in South African cultural contexts, PeetersPers, Leuven. (Liturgia Condenda 19)

Wepener, C.J., 2011a, 'Liminality: Recent avatars of this notion in a South African Context', Jaarboek voor liturgie-onderzoek/Yearbook for Liturgical and Ritual Studies 27, 189-208. 
Wepener, C.J., 2011b, 'Nuwe tendense buite-om die erediens van die 21ste eeu: ' $n$ Beskrywende liturgie-historiese en hedendaagse verkenning', Nederduitse Gereformeerde Teologiese Tydskrif 52(1/2), 257-271.

Wepener, C.J., 2013, 'Die Liturgiereform in Afrika südlich der Sahara. Einige Beobachtungen zu Gottesdienst, Sprache und Kultur', in G. Lathrop \& M. Stuflesse (eds.), Liturgiereformen in den Kirchen. 50 Jahre nach Sacrosanctum Concilium, Theologie der Liturgie 5, pp. 161-176, Verlag Friedrich Pustet, Regensburg.

Wepener, C.J., Mbaya, H. \& Barnard, M., 2011, 'Worship in the Corinthian Church (AIC), in Phepheni, Eastern Cape, South Africa', Studia Liturgica 41(2), 252-273.
Wepener, C.J. \& Meyer, E.E., 2012, 'Liturgical inculturation as a missionary perspective: Ritual burning and slaughtering in an AIC and Leviticus and Numbers', in
$\mathrm{H}$. Kruger, E. Orsmond \& $\mathrm{H}$. van Deventer (eds.), Perspectives on mission in the Old Testament: Pictures from chosen Old Testament literature, pp. 69-79, Bybelmedia, Wellington.

Wepener, C.J. \& Ter Haar, G., forthcoming, 'Sacred sites and spiritual power: One angel, two sites, many spirits', in P.G.J. Post \& P. Nel (eds.), Sacred sites, contested grounds: Space and ritual dynamics in Europe and Africa, African contested grounds: Space
World Press, Trenton, NJ. 